\title{
WHY ARE BRAZILIAN ORTHODONTISTS PROSECUTED AND CONVICTED? AN OVERVIEW OF THE CONTEMPORARY JURISPRUDENCE
}

\author{
POR QUE OS ORTODONTISTAS SÃO PROCESSADOS E CONDENADOS? UMA \\ REVISÃO DA JURISPRUDÊNCIA CONTEMPORÂNEA
}

\section{Fernando Fortes PICOLI ${ }^{1,5}$; Ademir FRANCO ${ }^{2,6}$; Mayara Barbosa Viandelli MUNDIM-PICOLI ${ }^{3}$; Luiz Renato PARANHOS ${ }^{4}$; Rhonan Ferreira SILVA,}

1. Department of Forensic Dentistry and Anthropology, Scientific Police, Goiânia, GO, Brazil; 2. Division of Oral Radiology, Faculdade São Leopoldo Mandic, Centro de Pesquisas São Leopoldo Mandic, Campinas, SP, Brazil. franco.gat@gmail.com; 3. Department of Dentistry, School of Dentistry, Forensic Dentistry, UniEvangélica, Anápolis, GO, Brazil; 4. Department of Preventive and Community Dentistry, School of Dentistry, Federal University of Uberlândia, Uberlândia, MG, Brazil; 5. Postgraduate Program in Dentistry, Department of Dentistry, School of Dentistry, Forensic Dentistry, Federal University of Goiás, Goiânia, GO, Brasil. rhonansilva@gmail.com; 6. Department of Therapeutic Stomatology, Institute of Dentistry, First Moscow State Medical University, Moscow, Russia. franco.gat@gmail.com

\begin{abstract}
Orthodontics figures as one of the largest community of specialists in Brazil. Unfortunately, numbers are high not only for the professionals but also for the lawsuits against them. The aim of this study was to screen the Brazilian jurisprudence in order to identify the reasons that motivated patients against orthodontists and motivated Judges towards convictions in lawsuits. The sample consisted of 395 lawsuits retrieved from the State Civil Courts of Brazil $(n=27)$. The lawsuits were founded on conflicts between orthodontists and patients. Case-specific legal information were registered, such as patients' main reason behind the lawsuit and the decision in second instance. Chi-square and relative risk tests were calculated to investigate the influence of research variables towards conviction. Most of the lawsuits were judged in the State of São Paulo ( $\mathrm{n}=151 ; 38.2 \%)$ and were published between 2011 and 2017 (rho: 0.797). The main reasons behind the lawsuits against orthodontists were the dissatisfaction with treatment outcomes $(n=143,36.2 \%)$, the occurrence of periodontal disease $(n=45,11.4 \%)$ and the need for tooth extractions $(n=43,10.9 \%)$. Statistically significant outcomes were detected between convictions in first and second instances and between convictions and the contractual obligation of result $(\mathrm{p}<0.001)$. The combination of I) patients' dissatisfaction and II) judgments under the obligation of results in second instance figure as the main risk factors for the prosecution and conviction of orthodontists.
\end{abstract}

KEYWORDS: Forensic Dentistry. Malpractice. Law. Orthodontics.

\section{INTRODUCTION}

Life in society requires daily attitudes and behavior guided by rules and legislation (RODRIGUES, 2003). Responsibility is the term given to the legal obligation of compensating moral or material damages caused to someone (VENOSA, 2015). According to the Brazilian Law, responsibility is also inherent to professional activities (SILVA et al., 2009). Specifically in Dentistry, the prosecution of professional attitudes may be founded on specific Laws, such as $n$. 5.081/66 (TERADA et al., 2014), the Consumer Protection Code (BRASIL, 1990) and the Brazilian Civil Code (BRASIL, 2002).

Forensic Dentistry is a large field of science that includes criminal (SHIMADA et al., 2017), civil and administrative investigations. Recently, civil investigations gained more space in the spotlight of the scientific community because of the evident increase of litigation in Dentistry. In particular, patients play a more active role in treatment decision (MINERVINO and SOUZA, 2004) and are gradually more aware of their rights (SILVA et al., 2009). This scenario triggered the need for major attention to consumer rights and highlighted the importance of legal knowledge in the clinical practice (PARANHOS et al., 2012). On the other hand, the number of lawsuits founded on dental treatments expanded considerably over the last years (BARBOSA et al., 2010; PARANHOS et al., 2013; ZANIN et al., 2016).

Orthodontics represent a specialty of Dentistry. According to the Brazilian Federal Council of Dentistry (standards approved by the Resolution \#065/2005), this specialty is dedicated to 
Why are brazilian orthodontists...

preventive, interceptive and corrective treatments of malocclusions and dentomaxillofacial disorders that involve the stomatognathic system (BRASIL, 2005). The number of Orthodontists in the field nearly multiplied four times along the last fourteen years growing from 6.428 (ETO and ANDRADE, 2012) to 27.045 (BRASIL, 2019) registered professionals. In this context, Orthodontics underwent changes and became one of the most prosecuted dental specialties in Brazil (CRUZ et al., 2010; PAULA et al., 2010; ETO and ANDRADE, 2012; FRANCO et al., 2012; CASTRO et al., 2015; ZANIN et al., 2016; BRASIL, 2019). Judicial claims of malpractice often occur and illustrate the scenario of orthodontic litigations in Brazil. From a clinical perspective, malpractice may be found in several ways, such as starting the Orthodontic treatment without proper initial radiographs and documents (more related to imprudence); using techniques scientifically proved wrong for certain disorders (more related to lack of expertise); and not intercepting growing disorders with proper timing (more related to negligence) (FRANCO et al., 2012). Despite the importance of malpractice in the orthodontic jurisprudence, several other factors might influence on judicial decisions.

Knowing the reasons behind the prosecutions in Orthodontics is the first step to avoid conflicts in Court (ZANIN et al., 2016). The present study aimed to perform a standardized search and analysis in the Brazilian jurisprudence to identify the main reasons that justified conflicts between patients and orthodontists, as well as the motives that led to convictions.

\section{MATERIAL AND METHODS}

The methods and the results presented in this work are part of the Master's Thesis of the first author (F.F.P.), which is available at the repository of the Federal University of Goiás - digital library of Theses and Dissertations.

\section{Study design and sample}

Search and analysis of the Brazilian jurisprudence was designed to retrieve lawsuits against orthodontists. All the websites of the State Civil Courts of Brazil were consulted $(n=27)$. Search strategy was customized for each website based on the available tools and mechanisms. In the websites, the legal information necessary for this study was retrieved from the jurisprudence link at homepage.

According to the eligibility criteria, only lawsuits published up to December 31th 2017 were
PICOLI, F. F. et al.

selected. The exclusion criteria consisted of lawsuits that 1) were not established in the Civil Courts; 2) were not established based on orthodontic malpractice; and 3) were not established against an orthodontist or a dental clinic.

Because the lawsuits were written in the Portuguese language, the search was conducted with Descriptors in Health Sciences (DeCS: http://decs.bvs.br/) associated or not with terms commonly used in orthodontics. The following terms were used: "Ortodontia"; "Odontologia"; "Erro" AND "Odontológico"; "Erro" AND "Odontologia"; "Aparelho" AND "Dentário"; "Dentário". Depending on the website, the Boolean operator "AND" was not available. In these cases, the terms were simply written together, such as "Erro Odontologia".

The sample selection process was conducted in two phases. In the first, the summary of the lawsuits were read by single examiner - a dentist specialist in Orthodontist and Forensic Dentistry with nearly 15 years of experience in practice. This phase enabled the exclusion of lawsuits not established based in Civil Courts. If the necessary information for inclusion/exclusion of the lawsuit was not available or clear in the summary, full-text reading was accomplished. In the second phase, the included lawsuits were read in full-text by the same examiner. If no exclusion criteria were detected, the lawsuits were considered eligible and stored for data collection.

Data collection was performed by two dentists - the main examiner and an additional Orthodontist also specialist in Forensic Dentistry also with nearly 15 years of experience experienced. The collected data were: 1) the geographic location of the Civil Court; 2) the Brazilian State in which the Court was located; 3) the identification code of the lawsuit; 4) the year of publication of the Court decision; 5) the length of the orthodontic treatment (expressed in years); 6) patients' main reason behind the lawsuit; 7) the type of defendant (orthodontist or dental clinic); 8) the first instance decision; 9) the second instance decision; 10) the type of contractual obligation between orthodontist and patient.

\section{Statistical Analysis}

Initially, descriptive data analysis was performed. A linear regression analysis was performed to verify the correlation between the prevalence of lawsuits based on their year of publication. Next, Chi-square test was used to assess the eventual frequencies of convictions in face of the different variables. In case of statistically 
Why are brazilian orthodontists...

significant differences, the relative risks were calculated $(\alpha=5 \%)$. The statistical tests were performed with IBM SPSS 20.0.0 (IBM Corp., Chicago, IL, USA) software package.

\section{RESULTS}

In the first phase of sample selection, 6973 lawsuits were initially screened. Considering the exclusion criteria, were excluded: the lawsuits that were not established in the Civil Court $(n=4.475)$, the lawsuits the were not related to orthodontics treatments $(\mathrm{n}=1.770)$, the lawsuits with duplicates $(n=305)$ and the lawsuits nullified or in which the
PICOLI, F. F. et al.

sentence was other than conviction or acquittance $(n=28)$. The final sample consisted of 395 lawsuits (Figure 1).

\section{Study Characteristics and Synthesis of the Results}

Most of the lawsuits were established in the States of São Paulo ( $\mathrm{n}=151 ; 38.2 \%)$, Rio Grande do Sul $(n=83 ; 21 \%)$, Minas Gerais $(n=35 ; 8.9 \%)$ and Rio de Janeiro ( $\mathrm{n}=32 ; 8.1 \%)$ (Table 1$)$.

A strong positive correlation $(0.797, p<$ $0.05)$ was observed between the year of publication and the prevalence of lawsuits. Most of the lawsuits were published between 2011 and 2017 (Figure 2).

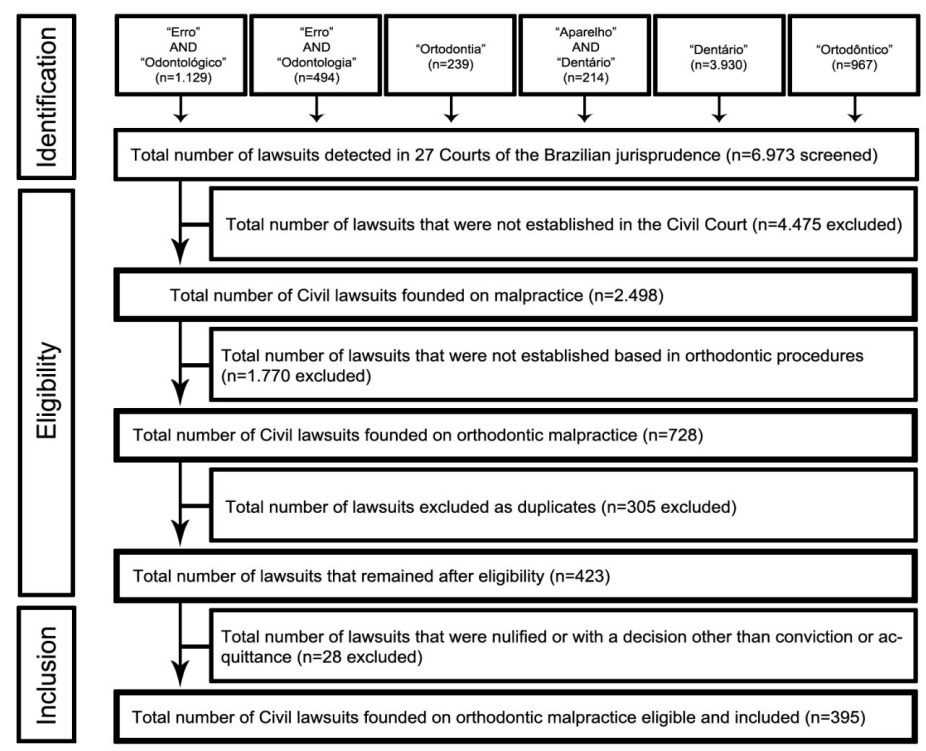

Figure 1. Standardized search strategy and outcomes performed in the Brazilian jurisprudence of Civil Courts

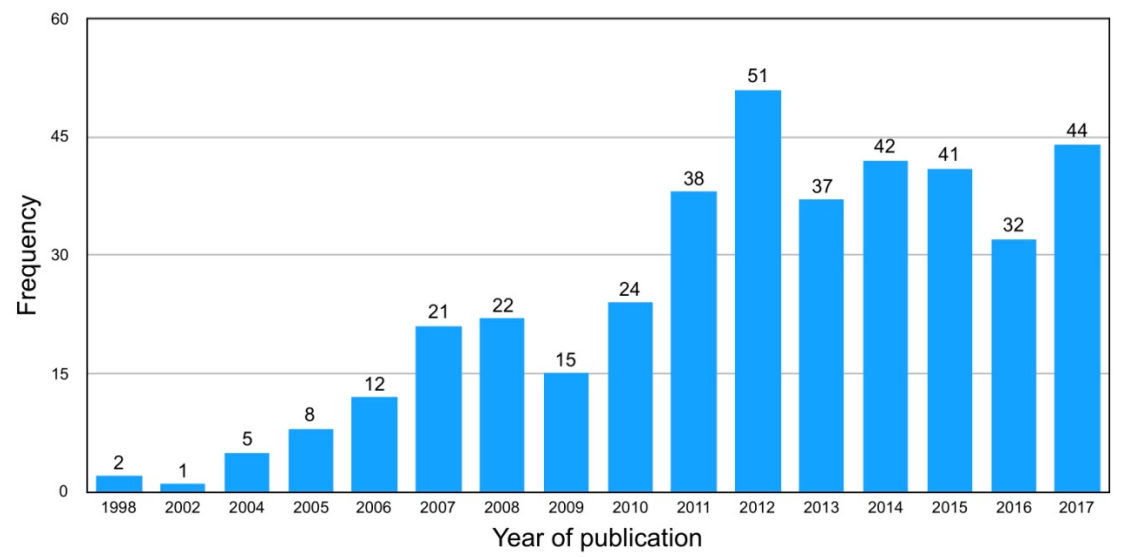

Figure 2. Absolute frequency of distribution of lawsuits from 1998 to 2017 in the Brazilian jurisprudence of Civil Courts

Only $52.9 \%$ of the lawsuits reported information about the length of the orthodontic treatment. The mean treatment length reached 3.91 years (from 0.3 years to 14 years of orthodontic treatment). 
Table 1. Frequencies of Civil lawsuits against orthodontists according to the State of origin in Brazil

\begin{tabular}{lcc}
\hline State & $\mathrm{n}$ & $\%$ \\
\hline São Paulo & 151 & 38.2 \\
Rio Grande do Sul & 83 & 21.0 \\
Minas Gerais & 35 & 8.9 \\
Rio de Janeiro & 32 & 8.1 \\
Distrito Federal & 23 & 5.8 \\
Paraná & 23 & 5.8 \\
Santa Catarina & 21 & 5.3 \\
Sergipe & 8 & 2.0 \\
Goiás & 4 & 1.0 \\
Mato Grosso & 3 & 0.8 \\
Rondônia & 3 & 0.8 \\
Roraima & 3 & 0.8 \\
Mato Grosso do Sul & 2 & 0.5 \\
Amazonas & 2 & 0.5 \\
Pernambuco & 1 & 0.3 \\
Bahia & 1 & 0.3 \\
Total & 395 & 100.0 \\
\hline
\end{tabular}

n: absolute frequency; \%: relative frequency.

Dissatisfaction with orthodontic treatment outcomes was the main reason behind the lawsuits $(\mathrm{n}=143,36.2 \%)$, followed by the occurrence of periodontal disease $(n=45,11.4 \%)$ and the need for tooth extractions $(\mathrm{n}=43,10.9 \%)$ during the treatment (Table 2).

Orthodontists were prosecuted exclusively in 220 lawsuits (55.7\%), while dental clinics were prosecuted 122 times $(30.9 \%)$. Orthodontist and clinics were prosecuted together in 53 lawsuits $(13.4 \%)$.

Orthodontist and dental clinics were convicted in $45.3 \%(n=179)$ and $47.3 \%(n=187)$ of the lawsuits in judged in first and second instances, respectively.

Only $42.5 \% \quad(n=168)$ of the lawsuits reported information regarding the type of contractual obligation. Out of these lawsuits, the obligation of result was detected in $73.8 \%(\mathrm{n}=124)$.

Table 2. Main reasons behind the Civil lawsuits against orthodontists

\begin{tabular}{lcc}
\hline Reason & $\mathbf{n}$ & $\mathbf{\%}$ \\
\hline Dissatisfaction with treatment outcomes & 143 & 36.2 \\
Ocurrence of periodontal diseases & 45 & 11.4 \\
Eventual need for extractions & 43 & 10.9 \\
Root resorption & 33 & 8.4 \\
Wrong diagnosis & 22 & 5.6 \\
Other oral/dental injuries & 15 & 3.8 \\
Pain and discomfort & 14 & 3.5 \\
Tooth loss & 11 & 2.8 \\
Ocurrence of caries & 9 & 2.3 \\
Long treatment lenght & 9 & 2.3 \\
Other & 34 & 8.5 \\
Indeterminate & 17 & 4.3 \\
Total & 395 & 100 \\
\hline
\end{tabular}

n: absolute frequency; \%: relative frequency. Other: unnecessary/wrong extractions, occurrence of pain in the temporomandibular joint, recurrent malocclusion, patient treated by auxiliary staff, failure of creating and storing dental documents, failure of informing patients about the treatment, unnecessary invasive tooth preparation, orthodontist refused to treat, facial lesions and lack of function, patient treated by several orthodontists, patient discussed in the reception, treatment was not necessary and patient was mistreated. 
Why are brazilian orthodontists...

PICOLI, F. F. et al.

Statistically significant associations with conviction were detected when the orthodontist/dental clinic was previously convicted in first instance $(\mathrm{p}<0.001)$ and when the orthodontist was judged under the contractual obligation of result (Table 3).

Table 3. Statistical association between the convictions in second instance and the inherent risk factors

\begin{tabular}{|c|c|c|c|c|c|c|}
\hline Risk fator & & $\mathbf{n}$ & Chi-square & $p$ & Relative risk & C.I. $(95 \%)$ \\
\hline \multirow{3}{*}{$\begin{array}{l}\text { Was the dentist } \\
\text { convicted in first } \\
\text { instance? }\end{array}$} & Yes & 157 & \multirow{3}{*}{213.97} & \multirow{3}{*}{$<0.001 *$} & \multirow{3}{*}{6.315} & \multirow{3}{*}{$4.51-8.842$} \\
\hline & No & 30 & & & & \\
\hline & & $\mathrm{n}=187$ & & & & \\
\hline \multirow{3}{*}{$\begin{array}{l}\text { Was the treatment } \\
\text { longer than } 3 \text { years? }\end{array}$} & Yes & 54 & \multirow{3}{*}{0.845} & \multirow{3}{*}{0.358} & \multirow{3}{*}{1.132} & \multirow{3}{*}{$0.869-1.475$} \\
\hline & No & 53 & & & & \\
\hline & & $\mathrm{n}=107$ & & & & \\
\hline \multirow{3}{*}{$\begin{array}{l}\text { Was the lawsuit } \\
\text { published after } 2011 ?\end{array}$} & Yes & 116 & \multirow{3}{*}{0.009} & \multirow{3}{*}{0.924} & \multirow{3}{*}{0.990} & \multirow{3}{*}{$0.799-1.226$} \\
\hline & No & 71 & & & & \\
\hline & & $\mathrm{n}=187$ & & & & \\
\hline \multirow{3}{*}{$\begin{array}{l}\text { Was the lawsuit } \\
\text { established against a } \\
\text { dental clinic? }\end{array}$} & Yes & 87 & \multirow{3}{*}{0.556} & \multirow{3}{*}{0.456} & \multirow{3}{*}{1.083} & \multirow{3}{*}{$0.879-1.333$} \\
\hline & No & 100 & & & & \\
\hline & & $\mathrm{n}=187$ & & & & \\
\hline \multirow{3}{*}{$\begin{array}{l}\text { Was the prosecution } \\
\text { judged under the } \\
\text { obligation of result? }\end{array}$} & Yes & 84 & \multirow{3}{*}{19.418} & \multirow{3}{*}{$<0.001 *$} & \multirow{3}{*}{2.293} & \multirow{3}{*}{$1.43-3.676$} \\
\hline & No & 13 & & & & \\
\hline & & $\mathrm{n}=97$ & & & & \\
\hline
\end{tabular}

C.I.: confidence interval; p: statistical significance set at 5\%.

\section{DISCUSSION}

Orthodontic treatment is usually seen as the final step in a group of dental treatments temporarily designed for a patient. However, it must be noted that orthodontic therapeutics extend to several other applications within groups of treatments, such as during oral rehabilitation with fixed prostheses and implants, periodontology, maxillofacial surgery and occlusion. The broad range of possibilities for orthodontic treatment makes of it a specialty that is susceptible to lawsuits - specifically because it became more accessible to patients and more commonly included in groups of treatments and procedures.

This study reported an increasing prevalence of lawsuits against Brazilian orthodontists in the last decade. This phenomenon was also observed by other authors in the previous scientific literature (PAULA et al., 2010). The outcomes obtained in this study could be explained in three ways. First, by the digitalization of lawsuits, that became gradually more common over the last twenty years. Second, by the release of the Brazilian Consumer Protection Code, in 1990 (HAAG and
FERES, 1999; TERRA et al., 2013; ALMEIDA et al., 2016), that changed the awareness of patients about the treatment. Third, by the growing number of Orthodontists that boosted the specialty in size, but not necessarily in quality. Ranked first among the recognized dentistry specialties in Brazil, Orthodontics consists of 27.045 professionals. Lack of expertise, skills and knowledge in the field leading from weak scientific foundations and poor academic training manifest within the alarming scenario depicted in Brazil.

This study was designed to retrieve only the lawsuits with decisions in second instance because in Brazil Court documents and systems are not yet completely digital. Thus, it is currently impossible to track all decisions in first instance from every city Court in the country. In the other hand, decisions in second instance are characterized when the orthodontist or the patient appeal the Court decision in first instance. Consequently, decisions in second instance are given in larger State Courts, which have digital systems that allow public navigation and research. In this study, most of the lawsuits were judged in the States of São Paulo, Rio Grande do Sul, Minas Gerais and Rio de Janeiro. Another 
aspect to be considered is the number of Orthodontists in these regions as well. It is estimated that the combined number of orthodontists in the four States reaches nearly 15.700, which contributes to the high rates of lawsuits detected in this study.

Similarly to this study, the scientific literature previously reported a higher prevalence of acquittals in Dentistry at second instance level (TERRA et al., 2000; ZANIN et al. 2011; FRANCO et al. 2012). However, no study reached a sample size larger than that collected in the present study. The reason behind the larger sample size may be explained by the standardized search structured to detect the highest quantity of lawsuits as possible. The combination of generic terms (using the Boolean operator AND), such as "Dentário" and "Odontológico", with legal terms, such as "erro", enabled the search for lawsuits in which the "Ortodontia" or "Ortodôntico" were missing or misspelled. Misused terms are commonly found in the routine of Law when materials, techniques and procedures are described by professionals that are not familiarized with Dentistry. Another aspect that justifies the large sample size in this study compared to previous studies relies on the constant and progressive number of lawsuits that are established over the time. In short: the more recent the study the larger the sample size.

The main focus of this study was analyzing the lawsuits in the search for the reasons that justify patients to undergo legal disputes with orthodontists. Dissatisfaction with the treatment outcomes figured as the most prevalent motivation behind the lawsuits. In most of the lawsuits, the lack of treatment success after orthodontic treatment was subjectively stressed - especially by patients. In other words, there was no clear justification that could specify the exact meaning of an unsuccessful treatment. This outcome may be interpreted in the sense that patients' complaints are founded on frustration with the treatment and not with the occurrence of a particular problem. In this context, two main factors must be considered: the real outcomes of the orthodontic treatment and the perception of each patient regarding the treatment outcomes. Unfortunately, the lawsuits documented in the Brazilian Courts do not allow a deeper look of the technical aspects of the orthodontic treatment. However, in a consumer relation, assessing the patient's satisfaction with the treatment is even more important than analyzing the treatment outcome itself.

In Orthodontics, the treatment outcomes may be assessed from patient's and orthodontist's perspectives, and even among orthodontists the opinions may be different regarding treatment success of not. To overcome the subjectivity inherent to judging the orthodontic treatment success, communication is a key tool. Patients must be informed not only about their expectation with the final aspect and alignment of their teeth, but also about the discomfort and pain that he will experience during the treatment. Discomfort and pain may be associated with psychological reactions (YAO et al., 2016) that may induce the patient to believe that the treatment is not succeeding (ALOMIRI and ABU ALHAIJA, 2006), while in fact it is. Communicating to the patients the limitations of the treatment and explaining that their expectations may not be reached (even in the absence of malpractice) is a fundamental step prior to the treatment itself. From a legal point of view and for safety purposes, all the communication between Orthodontist and patient must be clearly presented in written documents to be signed by both parts. This attitude may avoid future lawsuits based on dissatisfaction and frustration with the treatment outcomes.

Communication is also the keyword to avoid lawsuits justified in conflicting situations between the patient and orthodontist or his staff. In the United States, these conflicts are ranked in the top of the motives behind lawsuits in Orthodontics (MACHEN, 1992) and may be explained by the different levels of education of patients, orthodontists and staff as well as their ability to manage daily situations in the dental office. Similarly, a recent study interviewed Brazilian Law professionals, orthodontists and orthodontic patients and found out that failure in patient-professional relationship was the main triggering factor behind a lawsuit (GUEDES et al., 2018).

Once the lawsuit is not avoided, orthodontists may be convicted in a Civil Court. This study showed that orthodontists convicted in first instance due to an alleged malpractice have a six-time higher risk of being convicted after appealing to a second instance decision. However, it is important to note that even when the decision is maintained in the second instance, the indemnity costs may change from case to case. For this reason, these outcomes may be informative to support the orthodontists when deciding between an appeal to the second instance or not.

Initially, the orthodontic treatment length was expected to be a variable that could influence on conviction decisions. However, no difference statistically significant was observed between patients that were treated for more or less than 3 
Why are brazilian orthodontists...

years. Despite this outcome, the treatment length is a type of information that most of the patients ask in the orthodontic routine. Estimating the treatment length with uncertainty is a risky attitude that may influence patients' expectations and lead to lawsuits. Additionally, patients ongoing long treatment are more exposed to the potential accidents and complications inherent to orthodontics. It has been reported that longer orthodontic treatments have a negative impact on patients' attitude, especially when it comes to the maintenance of periodontal health (ALHAIJA et al., 2018) and the occurrence of caries (PINTO et al., 2018).

Another variable that was considered potentially able to influence on conviction decision was the year of publication of the judicial decision. This variable was stratified in before or after 2011 because this was the year in which the jurisprudence of the Brazilian Superior Court of Justice strengthened the idea that results should be achieved in orthodontic treatments (BRASIL, 2011). Statistically significant differences were not detected between decision published before or after 2011. This finding may indicate that Orthodontics was already judged this way before 2011 or that decisions are made case-specific as previously recommended in the scientific literature (PRADO et al., 2016).

An additional risk factor that could influence on conviction decisions was the existence of a dental clinic (and not solely the orthodontist) in the prosecution. According to the Brazilian Consumer Protection Code, dental clinics respond to any eventual damage caused to the patients independently of the culpability. Dentists or orthodontists respond oppositely - in this case, culpability needs to be verified (SILVA, 2008). The outcomes showed no statistically significant difference between lawsuits against dental clinics or orthodontists. In practice it may indicate that dental clinics are well supported legally and administratively against conflicts and disputes in Court. Robust legal support is more evident in large dental clinics that work not only with orthodontists but also many other specialists in Dentistry. In practice, joining the clinic into the lawsuit figure as an indirect process to open the market to highly skilled and trained professionals - because those will be searched for clinics that want to avoid lawsuits based on malpractice.

The final risk factor that was investigated in face of its potential negative impact on conviction decision was the type of contractual obligation. Statistically significant differences were observed between the obligation of result and the obligation
PICOLI, F. F. et al.

of conduct. More specifically, orthodontists judged under the obligation of result had twice the risk of getting convicted compared to those judged under the obligation of conduct. This outcome corroborates the fear or concern that each orthodontist has of being judged based on the final outcomes of the treatment - especially because the orthodontic treatment does not depend exclusively on the orthodontist and his technique, but also on patient's participation and biological response. Moreover, this finding is probably the most palpable and applicable in practice among those obtained in this study. The contemporary Orthodontics suffers from a highly competitive market in which professionals use all their tools to reach and captivate patients. "Before and after" photographs emerge in this context as marketing strategies that may influence on patients' expectations, leading to frustrations after the treatment, and culminating in lawsuits judged under the obligation of results. In order to perform more safely under the obligation of result in practice, orthodontists must inform their patients about the potential limitations of their cases and the level of success that he may reach by the end of the treatment. All the communication must be registered in contract and the lack of it may be interpreted in Court as the prediction of complete aesthetic and functional success in every case. From an academic perspective, knowledge and awareness of the Law proper and the documents to be used in the daily practice must be provided early from undergrad level. Education in Orthodontics is a major concern nowadays (BRANDÃO et al., 2016) as has a close connection with the attitudes and behavior of professionals in practice.

Knowing the reasons behind lawsuits in Orthodontics is essential to better understand the patients and avoid future disputes in Court. Unfortunately, the orthodontic treatment and the perception of its outcomes are subjective procedures that may be influenced by the several variables analyzed in this study. Among the factors that might influence lawsuits and outcomes, the conditions that led to the conflict between patient and orthodontist must be considered as well. Reliable examples may be found in cases that involve history of periodontal disease and need for extractions. It is important to note, however, that the number of lawsuits addressed in this study is possibly underreported and underestimated because it reflects only cases digitally available in Courts' online systems. In many, cities of Brazil, lawsuit procedural systems rely in hardcopies and are not aided by computerguided tools. Future studies in the field should keep tracking and screening lawsuits, not only in digital 
Why are brazilian orthodontists...

systems, to detect any changes in risk factors over the time or any behavioral alterations that modify patients' reasons behind the lawsuits. This study also encourages similar standardized research in international Courts to enable comparisons between countries.

\section{CONCLUSION}

An increase of lawsuits against orthodontists was detected in Brazil along the recent years. Brazilian orthodontists are prosecuted
PICOLI, F. F. et al.

because of patients' dissatisfaction with treatment outcomes. Risk factors for conviction included judgment under the obligation of results and judgments in second instance.

\section{ACKNOWLEDGMENTS}

This study was financed in part by CAPES Finance Code 001 and FAPEG (Goiás State Research Foundation). We are also thankful for the support of $\mathrm{CNPq}$ (Council for Scientific and Technological Development - Brazil).

RESUMO: A Ortodontia figura como uma das maiores especialidades no Brasil. Infelizmente, os números não são elevados apenas no que concerne aos profissionais, mas também quanto aos processos judiciais contra eles. O objetivo deste trabalho foi pesquisar a jurisprudência Brasileira para identificar as razões que levam os Ortodontistas a serem processados pelos pacientes e os motivos que levam os Magistrados a condená-los. A amostra consistiu de 395 processos judiciais obtidos dos Tribunais Judiciais Brasileiros $(\mathrm{n}=27)$. Todos os processos descreveram lides entre Ortodontistas e pacientes. Informações demográficas e legais foram registradas, como a queixa principal do paciente ao instaurar o processo e a decisão do Magistrado em segunda instância. Os testes de Qui-quadrado e de risco relativo foram utilizados para verificar a influência das variáveis sobre o desfecho. A maioria dos processos foi julgada no Estado de São Paulo (n=151; 38.2\%) e publicada entre 2011 e 2017 (rho: 0.797). O principal motivo de processo contra Ortodontistas foi a insatisfação do paciente com os resultados do tratamento $(\mathrm{n}=143,36.2 \%)$, seguido da ocorrência de doença periodontal $(n=45,11.4 \%)$ e da necessidade de extrações $(n=43,10.9 \%)$. Resultados estatisticamente significantes foram observados entre julgamentos em primeira e segunda instância e entre condenação e julgamento sob a obrigação de resultado $(\mathrm{p}<0.001)$. A combinação da I) insatisfação do paciente com II) o julgamentos sob a obrigação de resultados emergiram como principais fatores de risco para condenações.

PALAVRAS-CHAVE: Odontologia Legal. Erro odontológico. Direito. Ortodontia.

\section{REFERENCES}

ALHAIJA, E. S. A.; AL-SAIF, E. M.; TAANI, D. Q. Periodontal health knowledge and awareness among subjects with fixed orthodontic appliance. Dental Press J. Orthod., Maringá, v. 2, n. 5, p. e1-9, sep-oct. 2018. https://doi.org/10.1590/2177-6709.23.5.40.e1-9.onl

ALMEIDA, V. L. DE, KAIEDA, A. K., SILVA, L. O., RODRIGUES, J. L. S. DE A., BROLL, D., REPEKE, C. E. P., PARANHOS, L. R.. Professional profile, legal obligations, and conduct of orthodontists in terms of litigation prevention. Biosci. J., Uberlândia, v. 32, n. 3, p. 829-838, may-jun. 2016.

https://doi.org/10.14393/BJ-v32n3a2016-32824

AL-OMIRI, M. K., ABU ALHAIJA, E. S. Factors affecting patient satisfaction after orthodontic treatment. Angle Orthod., Toronto, v. 76, n. 3, p. 422-431, may. 2006.

BARBOSA, A. C. F., BARBOSA, M. J. L., MARCHIORI, G. E., MENDES, T. E., PARANHOS, L. R.. Decisions of the courts of justice regarding orthodontists' obligations: a 10-year review. Biosci. J., Uberlândia, v. 29, n. 5, p. 1388-1394. aug. 2013.

BARBOSA, G. G. R., RADICCHI, R., MARTELLI, D. R. B., CASTRO, H. A. L., COSTA, F. J. J., MARTELLI JÚNIOR, H... The profile of orthodontists in relation to the legal aspects of dental records. Dental Press J. Orthod., Maringá, v. 15, n. 2, p. 105-112, mar-apr. 2010. 
Why are brazilian orthodontists...

PICOLI, F. F. et al.

BRANDÃO, A. M. M., BRANDÃO, G. A. M., DE JESUS, A. S., FLÓRIO, F. M.. Profile of orthodontic education in brazilian undergraduate dentistry courses. Biosci J., Uberlândia, v. 33, n. 2, p. 555-65, mar-apr. 2017. https://doi.org/10.14393/BJ-v33n2-34878

BRASIL. Consolidação das normas para procedimetnos nos conselhos de odontologia (aprovada pela resolução \#065/2005). Brasília: Conselho Federal de Odontologia; 2005.

BRASIL. Lei 8.078 de 11 de setembro. Dispõe sobre a proteção do consumidor e dá outras providências. 1990.

BRASIL. Lei 10.406 de 10 de janeiro. Institui o Código Civil. 2002.

BRASIL. Superior Tribunal de Justiça. Recurso Especial n. 1.238.746 - MS Relator: Ministro Luis Felipe Salomão. 2011.

BRASIL. Conselho Federal de Odontologia. Quantidade geral de Cirurgiões-dentistas especialistas. 2019. Disponível em: <www.cfo.org.br/website/estatisticas> Acesso em: 1 july 2019.

CASTRO, A. C. C. A., FRANCO, A., SILVA, R. F. D., PORTILHO, C. D. M., DE OLIVEIRA, H. C. M.. Prevalence and content of legal suit founded on dental malpractice in the courts of midwest Brazil. RBOL., São Paulo, v. 2, n. 1, p. 46-52, jul 2015. https://doi.org/10.21117/rbol.v2i1.20

CRUZ, R. M., CHAVES CRUZ, C. P. A. Gerenciamento de riscos na prática ortodôntica: como se proteger de eventuais problemas legais. Dental Press J. Orthod., Maringá, v. 13, n. 1, p. 141-156, feb. 2008. https://doi.org/10.1590/S1415-54192008000100015

ETO, L. F., ANDRADE, V. M. N. The orthodontist's profile in Minas Gerais. Dental Press J. Orthod., Maringá, v. 17, n. 3, p. 1-9, may-jun 2012. https://doi.org/10.1590/S2176-94512012000300005

FRANCISCO, R. A., VILLALOBOS, M. I. DE O. E B., ORTIZ, A. G., BIAZEVIC, M. G. H., GUIMARÃES, M. A., DA SILVA, R. H. A... The use of human teeth in identification: epidemiological data from an anthropology lab in Brazil. Biosci. J., Uberlândia, v. 32, n. 2, p. 560-565, mar-apr. 2016. https://doi.org/10.14393/BJ-v32n2a2016-30195

FRANCO, A., ALQERBAN, A., DE LIMA, A. A., TANAKA, O. M., FRANÇA, B. H.. The orthodontist's responsibility and the bioethical aspects in the current jurisprudence. Eur. J. Gen. Dent., Kirikkale, v. 1, n. 1, p. 20-23, sep. 2012. https://doi.org/10.4103/2278-9626.101350

GUEDES, C. R. S., LEITE, I. C. G., CAMPOS, M. J. S., MOTA JÚNIOR, S. L., PHITON, M. M., VITRAL, R. W. F... Plain access to justice and the orthodontist's activity in Brazil: vulnerability in the professional practice in the face of risks of malpractice lawsuits. Dental Press J. Orthod., Maringá, v. 23, n. 4, p. 88-93, jul-aug. 2018. https://doi.org/10.1590/2177-6709.23.4.088-093.sar

HAAG, C. A., FERES, M. A. L. Legal and ethical aspects of the orthodontics in Brazil. Ortodontia, São Paulo, v. 32, n. 2, p. 67-81, may-aug. 1999.

MACHEN, D. E. Legal Issues in Orthodontics. J. Clin. Orthod., Greenwood Village, v. 25, n. 6, p. 347-352, jun. 1992.

MINERVINO, B., SOUZA, O. T. The orthodontist's civil and ethical responsibility. Dental Press J. Orthod., Maringá, v. 9, n. 6, p. 90-96, nov-dec. 2004. https://doi.org/10.1590/S1415-54192004000600013

MIZRAHI, E. Risk management in clinical practice. Part 7. Dento-legal aspects of orthodontic practice. $\mathbf{B r}$ Dent J, London, v. 209, n. 8, p. 381-390, oct. 2010. https://doi.org/10.1038/sj.bdj.2010.926 
Why are brazilian orthodontists...

PICOLI, F. F. et al.

PARANHOS, L. R., BENEDICTO, E. N., FERNANDES, M. M., QUELUZ, D. P., DARUGE, E., TORRES, F. C.. Ethical and legal considerations on professional liability of the orthodontist. Dental Press J. Orthod., Maringá, v. 17, n. 6, p. 146-153, dec. 2012. https://doi.org/10.1590/S2176-94512012000600026

PARANHOS, L. R., DE MAGAlHAES, M. P., FRANCIO, J., TERADA, H. H., ROSARIO, H. D., SILVA, R. F.. Time of guard of orthodontic records versus legal time for their prescription. Dental Press J. Orthod., Maringá, v. 18, n. 3, p. 113-117. 2013. https://doi.org/10.1590/S2176-94512013000300018

PAULA, F. J., MOTTA, M. V., BERSÁCOLA, R. N., MUÑOZ, D. R., DA SILVA, M.. Scenario of civil liability actions against dentists in Brazilian courts. Rev. Paul. Odontol., São Paulo, v. 32, n. 4, p. 22-28, octdec. 2010.

PINTO, A. S., ALVES, L. S., MALTZ, M., SUSIN, C., ZENKNER, J. E. A.. Does the duration of fixed orthodontic treatment affect caries activity among adolescents and young adults? Caries Res., Basel, v. 52, $\mathrm{n}$. 6, p. 463-467, apr. 2018. https://doi.org/10.1159/000488209

PRADO, M. M., LOPES, A. P. G., AQUINO, R. S., MENDANHA, M. H.. Orthodontics and the interpretation of its obligatory nature: analysis of the potential impact of a decision from the Superior Court of Justice (STJ). RBOL, São Paulo, v. 3, n. 2, p. 53-65, jul. 2016.

RODRIGUES, S. Direito Civil. 20. ed. São Paulo: Editora Saraiva, 2003. https://doi.org/10.21117/rbol.v3i2.5

SHIMADA, S. S., DA SILVA, C., RODRIGUES, L. G., SILVA, R. F., DE TORRES, M., SHIMADA, R. T.. Odontometric analysis of permanent canines in a brazilian population for the investigation of sexual dimorphism. Biosci. J., Uberlândia, v. 32, n. 5, p. 1422-1427, sep-oct. 2016. https://doi.org/10.14393/BJv32n1a2016-34200

SILVA, J. A. Q. C. Código de defesa do consumidor anotado e legislação complementar. 6. ed. São Paulo: Editora Saraiva, 2008.

SILVA, R. F., FELTER, M., TOLENTINO, P. H. M. P., ANDRADE, M. G. B. DE A., RODRIGUES, L. G., \& FRANCO, A.. Forensic importance of intraoral photographs for human identification in dental autopsies - a case report. Biosci. J., Uberlândia, v. 33, n. 6, p. 1696-1700, nov-dec. 2017. https://doi.org/10.14393/BJv33n6a2017-38605

SILVA, R. H. A., MUSSE, J. O., MELANI, R. F. H., OLIVEIRA, R. N.. Surgeon dentist's civil liability: The technical assistant's importance. Dental Press J. Orthod., Maringá, v. 14, n. 6, p. 65-71, dec. 2009.

TERADA, A. S. S. D., DE ARAÚJO, L. G., FLORES, M. R. P., SILVA, R. H. A.. Civil liability of dental surgeon: legal proceedings analysis in the city of Ribeirao Preto, São Paulo State, Brazil. Int. J.

Odontostomatol., Temuco, v. 8, n. 3, p. 365-369, dec. 2014.

TERRA, M., MAJOLO, M. S., CARILLO, V. E. B. Professional liability, ethics and the patient in orthodontics, Ortodontia, São Paulo, v. 33, n. 3, p. 74-85, sep-dec. 2000.

VENOSA, S. S. Direito Civil: responsabilidade civil. 1. ed. São Paulo: Editora Atlas, 2015.

YAO, J., LI, D. D., YANG, Y. Q., MCGRATH, C. P., MATTHEOS, N.. What are patients' expectations of orthodontic treatment: a systematic review. BMC Oral Health, London, v. 16, n. 19, feb. 2016.

https://doi.org/10.1186/s12903-016-0182-3

ZANIN, A. A., HERRERA, L. M., MELANI, R. F. Civil liability: characterization of the demand for lawsuits against dentists. Braz. Oral Res., Campinas, v. 30, n. 1, p. 1-8, aug. 2016. https://doi.org/10.1590/18073107BOR-2016.vol30.0091 